\title{
A note on cytogenetic monitoring of Polish Red cattle*
}

\author{
E. Słota ${ }^{1,3}$, A. Kozubska-Sobocińska ${ }^{1}$, B. Danielak-Czech ${ }^{1}$, \\ B. Rejduch ${ }^{1}$, P. Kowol ${ }^{2}$ and A. Żyga ${ }^{1}$ \\ ${ }^{I}$ National Research Institute of Animal Production, \\ Department of Immuno- and Cytogenetics \\ Krakowska 1, 32-083 Balice, Poland \\ ${ }^{2}$ National Animal Breeding Centre in Warsaw, Branch in Cracow \\ Cmentarna 6, 32-080 Zabierzów, Poland
}

(Received 5 June 2003; revised version 23 October 2003; accepted 14 January 2004)

\begin{abstract}
The cytogenetic control system of bulls sent to AI stations has been in use in Poland since 1989 and it is aimed to eliminate from breeding the bulls and semen of sires affected by chromosome abnormalities, with provision for extension of the studies with family material. In the years 1989-2002 451 animals of Polish Red cattle were cytogenetically investigated and in this population four cases of $60, \mathrm{XX} / 60, \mathrm{XY}$ leucocyte chimerism and three cases of 1;29 Robertsonian translocation had been found. The aberration carriers were not related. The next four cases of 1;29 Robertsonian translocation, recently diagnosed (2003) in a herd of Polish Red cattle, suggest the need for cytogenetic monitoring of genetic reserve breeds of cattle that would also account for females.
\end{abstract}

KEY WORDS: Polish Red cattle, cytogenetic monitoring, 1;29 translocation

\section{INTRODUCTION}

The purpose of the cytogenetic control system of bulls sent to AI stations, which has been used in Poland since 1989, is to eliminate from breeding the bulls and semen of sires affected by chromosome abnormalities, with provision for extension of the studies with family material.

Currently, Polish Red cattle accounts for about $0.8 \%$ of the Polish cattle population. This autochthonous dual-purpose breed has been little changed by selection and is very well adjusted to harsh environmental conditions. In view

\footnotetext{
${ }^{*}$ This work was conducted as a part of NRIAP statutory Project No. 3203.1

${ }^{3}$ Corresponding author: e-mail: eslota@izoo.krakow.pl
} 
of the breed's high fertility and superior composition of milk high in solids, fat and protein (Czaja et al., 1996), conservative herds were established as a genetic reserve for breeding Polish Red cattle. The population of this breed is decreasing by the year. Some herds were officially closed down, which made it necessary to establish a genetic reserve which currently stands at about 500 cows.

Polish Red bulls intended for reproduction have been under karyotype control since 1989, while females were controlled only sporadically. The present paper reports four recent cases of 1;29 translocation in a family of Polish Red cattle, as well as the results of cytogenetic control of this breed performed in 1990-2002, possibly suggesting the need for including females in the monitoring of genetic reserve herds.

\section{MATERIAL AND METHODS}

\section{Animals}

Four animals from an individual farm in Szaflary (Podhale region), related to a Polish Red bull (reg. no. 70100-3-8), a carrier of 1;29 Robertsonian translocation diagnosed as part of the current routine cytogenetic control, were investigated. The bull's mother, sister and half-sister were also studied.

These analyses were supplemented with the results of cytogenetic control of this breed performed in 1989-2002. In the karyotype evaluation 451 animals, from four different herds were included.

\section{Laboratory techniques}

Lymphocyte cultures from the animals' blood samples were performed according to the usual procedure. Metaphase chromosome preparations obtained after the culture were stained with Giemsa. GTG (Wang and Fedoroff, 1972) and RBA (Dutrillaux et al., 1973) banding techniques were used for accurate identification of the chromosomes involved in translocation and the resultant banding pattern was compared with the international ISCNDA standard (Di Berardino et al., 1990).

\section{RESULTS}

The four related Polish Red animals were diagnosed with a 1;29 centric fusion in the heterozygous form (Figure 1).

The GTG and RBA techniques confirmed that pair 1 and 29 chromosomes were engaged in the translocation (Figures 2 and 3). 


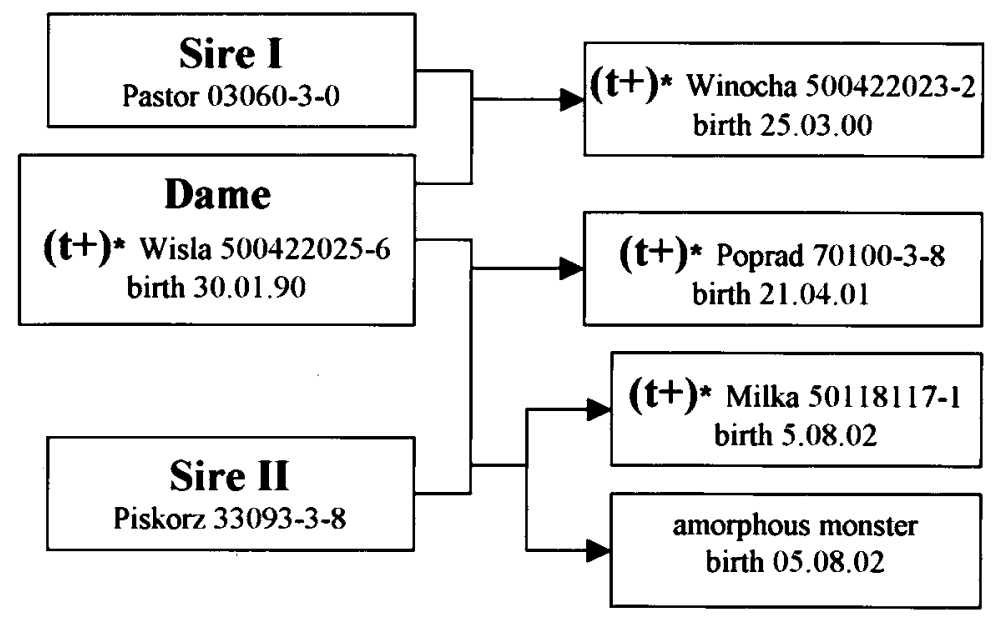

Figure 1. Diagram of relations between 1;29 translocation carriers

* Robertsonian translocation 1;29 carriers
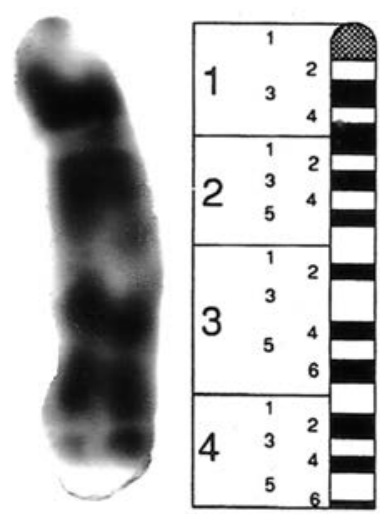

1
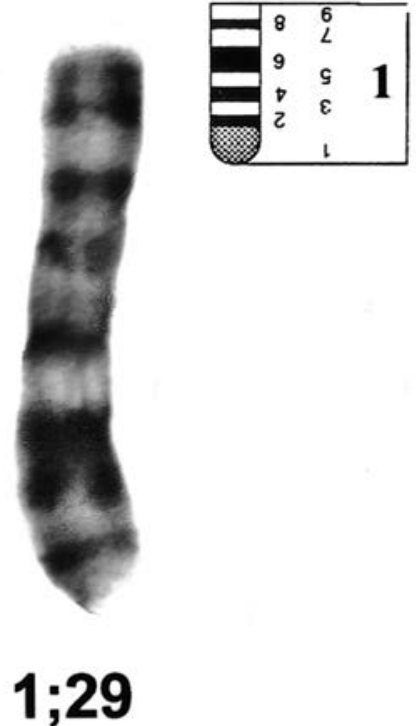
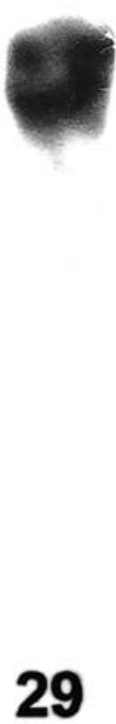

Figure 2. Comparison with idiogram of $\mathrm{G}$ banding patterns on 1;29 translocation chromosome and their homologues 

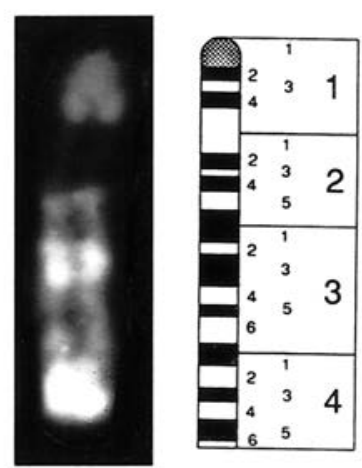

1
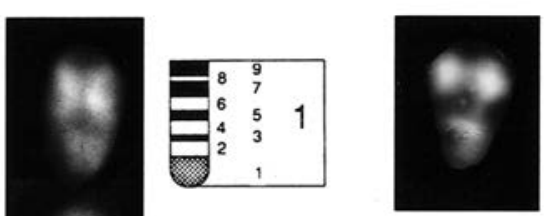

\section{9}

Figure 3. Comparison with idiogram of $\mathrm{R}$ banding patterns on 1;29 translocation chromosome and their homologue

It should be noted that the first animal in the family studies to carry a translocation was a young bull (Poprad, no. 70100-3-8) tested as part of the cytogenetic control system, while the karyotype of the other females (mother, sister and halfsister) were analysed at the request of the breeder after the aberration was diagnosed in the bull.

In Table 1 the results of cytogenetic control of 451 animals from four herds (in the Breeding Stations in: Jodłownik, Hańczowa, Ełk and Baranowo) were pre-

TABLE 1

Chromosomal aberrations diagnosed in Polish Red cattle under cytogenetic control at the National Research Institute of Animal Production in 1989-2002

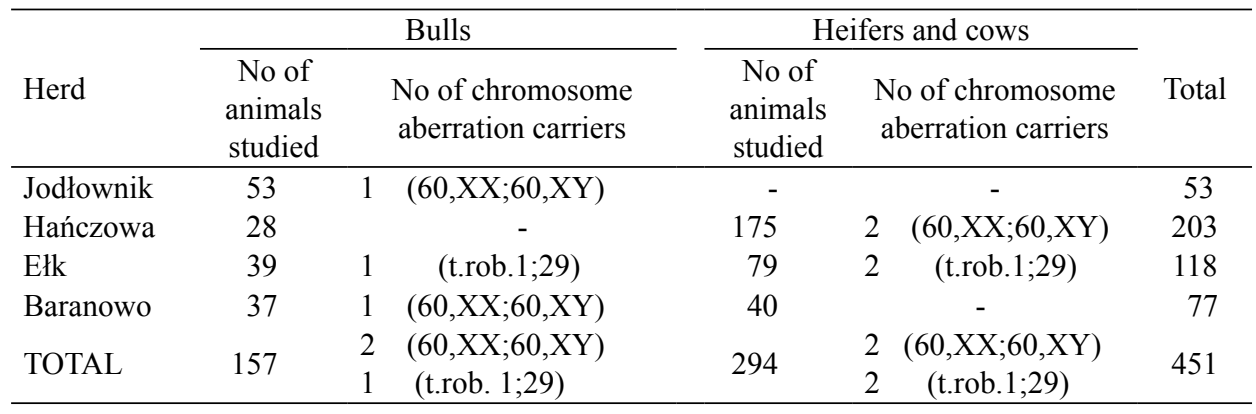


sented. Among this population three cases of 1;29 Robertsonian translocation as well as four cases of $60, \mathrm{XX} ; 60, \mathrm{XY}$ leucocytic chimerism were diagnosed.

\section{DISCUSSION}

For many years, the cytogenetic control systems of bulls intended for reproduction have been applied in EU countries, including Sweden, Denmark, France, Italy, Great Britain and Switzerland. Bovine karyotype analyses have shown a number of aberrations concerning both the number and structure of chromosomes.

In cattle, in the group of structural aberrations Robertsonian translocations were identified the most often. The most frequent of them was the translocation of pair 1 and 29 chromosomes, described in detail by Gustavsson (1969). Until today, 1;29 translocation in the Polish cattle population has been identified in Polish Red (Słota, unpublished data; Sysa, 1976), Black-and-White (Słota and Danielak, 1984), Charolais (Świtoński et al., 1991; Rejduch et al., 1994; Jędryczko and Sysa, 1998) and crosses of Polish Black-and-White cows with Blonde d'Aquitaine bulls (Rejduch et al., 1994).

In the Polish Red breed, 1 case of 1;29 Robertsonian translocation was identified in bull and 2 cases in cows from a conservative herd in Ełk (North-East Poland) (Table 1). The other 2 cases of 1;29 centric fusion in the young bulls were described earlier by Sysa (1976).

Robertsonian translocation 1;29 in heterozygous form is most often associated with reduced fertility indices in the carriers. Decreased fertility is due to the abnormal process of gametogenesis, which in turn leads to the death of aneuploid embryos (Gustavsson, 1969; Popescu, 1990). Centric fusions are passed onto the offspring according to Mendelian segregation (Gustavsson, 1969; Weber et al., 1989). If chromosome segregation takes a normal course, it results in gametes with a balanced karyotype. This produces either normal karyotype animals or translocation carriers. If chromosome segregation is abnormal, leading to defective gametes with deficient or excessive genetic material (aneuploid gametes), this produces a zygote with an unbalanced karyotype. The developing embryo dies during foetal growth.

One of the cytogenetically tested animals - heifer Milka no. 50118117-1 had a $59, \mathrm{XX}$, t.rob. $(1 ; 29)$ karyotype. It was born co-twin to a dead, amorphous monster. Because no cytogenetic tests could be performed on it, it is not certain whether the above translocation was responsible for the developmental changes, especially since aneuploid embryos are often aborted during the pre-implantation period. Eldridge (1980) described a case of two female lambs born co-twin to an amorphous monster whose karyotype was normal $(54, \mathrm{XX})$. The author suggests, however, that multiple pregnancy could affect the formation of such developmental defects. 
Analysis of data in Figure 1 shows that the aberration was transmitted to the offspring by a dam with 1;29 translocation (Wisła no. 50422025-6) born in 1990 . The fact that the translocation carrier was used for a long time in a small herd resulted in a significant increase in the incidence of this unfavourable karyotype change.

The first comprehensive studies of 1;29 translocation in cattle were carried out at the Research Institute of Animal Production in 1994 (Rejduch et al., 1994). They concerned closely related crossbreds of Polish Black-and-White cows graded up with Blonde d'Aquitaine bulls imported from France and originating from a common ancestor (bull - Ufigniac no. 2435604403). The chromosome aberration discussed was carried by 4 bulls and 10 heifers. In all the bulls and 9 heifers this anomaly occurred in heterozygous form, whereas one heifer was a homozogyte with 58,XX, rob. $(1 ; 29)$ karyotype. It inherited the translocation from both parents.

The results obtained and the literature data point to the need for applying cytogenetic control also to the population of cows, especially in small conservative herds in which the presence of a translocation carrier has a stronger effect on its frequency and in a short period of time increases the incidence of this genetic defect. Simulation models elaborated by Jędryczko (2001) for the incidence of 1;29 translocation in small populations suggest that in such herds, even when the translocation was relatively infrequent in the foundation population, translocation carriers can be expected to occur for as long as 40 years after the cytogenetic control system of bulls has been in operation.

\section{CONCLUSIONS}

This results indicates the need for constant monitoring of both male and female material particularly in small populations, such as those of conservative herds of Polish Red cattle.

\section{REFERENCES}

Czaja H., Adamik P., Trela J., Staszczak S., 1996. The breeding of Polish Red cattle - the past, present and future (in Polish). In: Proceedings of Symposium "Cattle Breeding in Poland. The History and Future”. Olsztyn Agricultural University (Editor), pp. 87-91

DiBerardino D., Hayes H., Fries R., Long S., 1990. ISCANDA 1989. International system of cytogenetic nomenclature of domestic animals. Cytogenet. Cell Genet. 53, 65-79

Dutrillaux B., Laurent C., Couturier J., Lejeune J., 1973. Coloration des chromosomes humaines par l'acridine orange après traitment par le 5-bromodeoxyuridine. C.R. Hebd. Seances. Acad. Sci. $276,3179-3181$ 
Eldridge F.E., 1980. Chromosomes of acardius amorphous lam. In: Proceedings of $4^{\text {th }}$ European Colloquium on Cytogenetics of Domestic Animals, pp. 17-22

Gustavsson I., 1969. Cytogenetics, distribution and phenotypic effect of a translocation in Swedish cattle. Hereditas 63, 67-169

Jędryczko R., Sysa P.S., 1998. Occurrence of 1/29 translocation in the imported Charolais cattle (in Polish). In: Proceedings of the XXXIV Scientific Meeting, Polanica Zdrój (Poland), p. 101

Jędryczko R., 2001. Estimation of the occurrence of chromosome aberrations in bulls meand for reproduction within the functional system of cytogenetic examination of bulls in Poland (in Polish). Ph.D. Thesis, Department of Veterinary Medicine of Olsztyn Agricultural University (Poland)

Popescu P.C., 1990. Chromosome of the cow and bull. Adv. Sci. Comp. Med. 34, 41-71

Rejduch B., Słota E., Świtoński M., 1994. Cytogenetic analysis of beef cattle. Genet. Pol. 35, 323332

Słota E., Danielak B., 1984. The case of 1/29 translocation in the cow of Black-White Breed (in Polish). Rocz. Nauk. Zoot. 11, 9-14

Sysa P.S., 1976. The 1/29 translocation in two young bulls of Polish Red Breed (in Polish). Med. wet. $32,353-355$

Świtoński M., Lechniak D., Landzwojczak D., 1991. Cytogenetic survey of bulls used in artificial insemination. Reproductive performance of XY/XX chimeric bulls. Genet. Pol. 32, 227-233

Wang H.C., Fedoroff S., 1972. Banding in human chromosomes treated with tripsin. Nature New Biol. 235, 52-53

Weber A.F., Buoen L.C., Terhaar B.L., Ruth G.R., Mamont H.W., 1989. New fertility related to 1/29 centric fusion anomaly in cattle. J. Amer. Vet. Med. Assn. 195, 643-646

\section{STRESZCZENIE}

\section{Monitoring cytogenetyczny bydla rasy polskiej czerwonej}

Funkcjonujący od 1989 roku w Polsce system kontroli cytogenetycznej buhajów kierowanych do Stacji Unasieniania ma na celu eliminację z rozrodu buhajów i nasienia rozpłodników obarczonych nieprawidłowościami chromosomowymi z ewentualnym rozszerzeniem badań o materiał rodzinowy. W latach 1989-2002 analizą kariotypu objęto 451 sztuk bydła rasy polskiej czerwonej. W tej populacji stwierdzono przypadki chimeryzmu leukocytarnego 60,XX/60,XY u 4 osobników oraz translokacji robertsonowskiej 1;29 u trzech zwierząt. Zdiagnozowane ostatnio (2003) kolejne cztery przypadki translokacji robertsonowskiej 1;29 w stadzie bydła rasy polskiej czerwonej sugerują konieczność monitoringu cytogenetycznego bydła ras zachowawczych, obejmującego także osobniki żeńskie. 